\title{
The wild Bactrian camel Camelus bactrianus ferus in China: the need for urgent action
}

\author{
John Hare
}

\author{
Between 31 March and 28 May 1995 and 5 April and 2 May 1996 two \\ expeditions carried out surveys of the status and distribution of the wild Bactrian \\ camel Camelus bactrianus ferus in the Xinjiang Uygur Autonomous Region \\ and Gansu Province in the People's Republic of China, the last known habitat of \\ the subspecies in the country. The surveys revealed that the wild camel is highly \\ endangered in China, due to illegal mining and hunting. An estimated total of \\ 380-500 individuals remain and immediate action is needed to ensure their \\ survival.
}

\section{Introduction}

The wild Bactrian camel Camelus bactrianus ferus was first identified in 1877 (Prejevalsky, 1879 ) and was subsequently observed in China by Littledale (1894) and Hedin (1898, 1903, 1934), among others. A number of Littledale's and Hedin's sightings were made in a sector of the Chinese Gobi known as the Gashun Gobi, which encompasses the driedup lake, Lop Nur. A large part of this area had, until our visit in 1995, been closed to foreigners for many years and little was known about the status and distribution of the camels. Bannikov (1976) surmised that they had 'disappeared without trace', while Zhirnov and Ilyinsky (1986) feared that they might be 'very few in number or totally extinct'. Gu and Gao (1985) crossed the Gashun Gobi from east to west in 1980 and 1981, where they estimated 'up to $200^{\prime}$ wild camels in the Lop Nur region. Their survey of the Aqike Valley to the south of Lop Nur in 1981 found 117-147 camels. Tulgat and Schaller (1991) presumed 'that there could still be up to 500 wild camels in China'.

Our expedition crossed the Gashun Gobi from north to south (twice) and from east to west, following two separate routes, in 1995 and 1996. In 1995 the expedition also visited three other areas inhabited by the wild camel in China.

\section{The surveys}

The surveys took place between 31 March and 28 May 1995, and between 5 April and 2 May 1996. The survey team comprised eight people in 1995 and seven in 1996. Travel was by jeep and and a six-wheel supply truck. Over 5500 $\mathrm{km}$ were covered in 1995, with some surveys being conducted by foot. Temperatures ranged from $-7^{\circ} \mathrm{C}$ at night to $30^{\circ} \mathrm{C}$ in the day, and on two occasions sand-storms occurred in excess of gale force 7. In 1996 the team covered over $3000 \mathrm{~km}$ by jeep and $65 \mathrm{~km}$ on foot. It encountered temperature variations between -10 and $25^{\circ} \mathrm{C}$, a sand-storm of gale force 7 in the Aqike Valley and a $59-\mathrm{mm}$ covering of snow south of the Kuruk Tagh mountains on 15 April.

Survey area A was visited in both 1995 and 1996. In 1995 the survey focused on areas north-west, north-east, east and south of Lop Nur, covering the southern slopes of the Kuruk Tagh mountains, the Gashun Gobi and the Aqike Valley north of the Kum Tagh sand dunes (Figure 1). This area is the only place in China where the camel is considered to be 


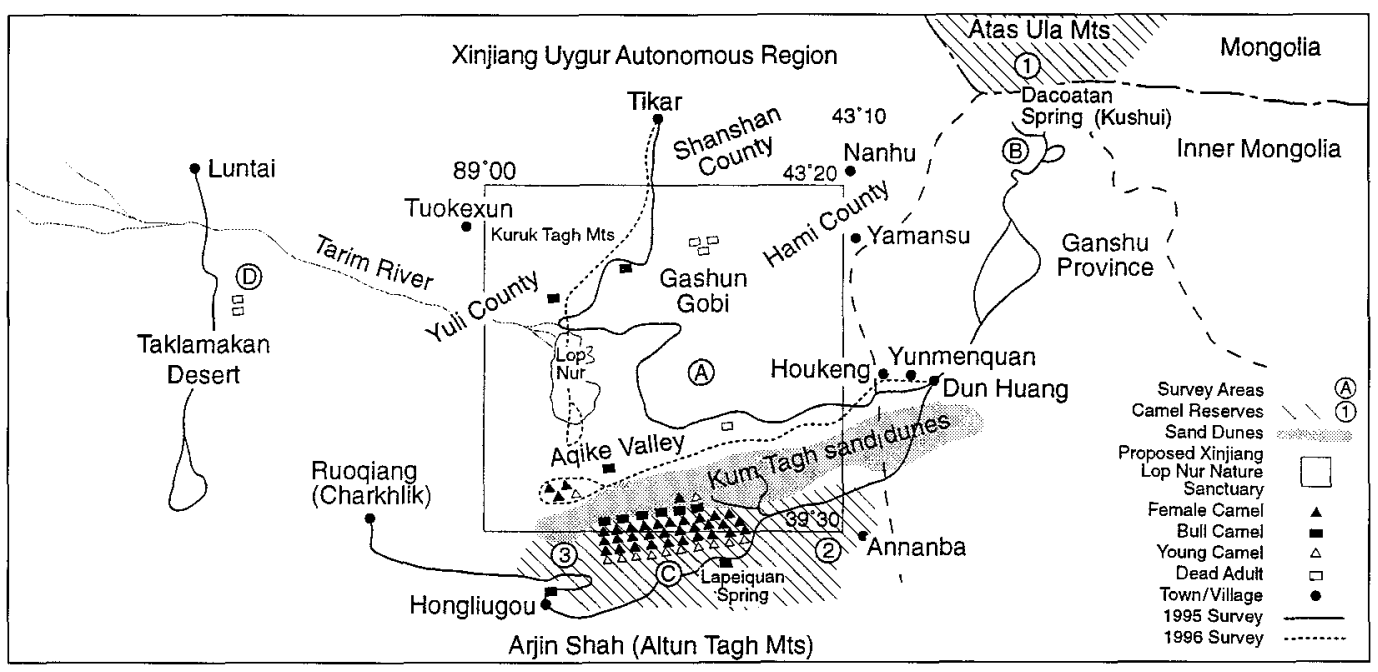

Figure 1. Map showing survey areas visited.

genetically pure, because it does not come into contact with domestic camels. The area is remote and until recent years there has been little human impact. It has good vegetation cover and is protected to the south by the Kum Tagh sand dunes. In 1996 a further survey followed a north-south route down through Lop Nur into the southern part of the Aqike Valley.

Survey area B was around the Dacoatan spring in Gansu Province (Figure 1). The spring lies $80 \mathrm{~km}$ south of the Atas Ula mountains, which are one of the principal habitats of the camel in the Great Gobi National Park in Mongolia. Camels from the park cross the border from Mongolia (Zhirnov and Ilyinsky, 1986) and travel through the $15-\mathrm{km}$ buffer zone to the spring. In 1990 the Chinese Government lifted a ban on mining in this area and as a result there is much mining activity, both legal and illegal, $100 \mathrm{~km}$ from the border. Most of the mining is for gold and highly toxic potassium cyanide, which is used in the gold extraction process, contaminates grazing over a considerable distance.

Survey area $C$ covered the northern slopes of the Arjin Shan (Altun Tagh) mountains from Annanba to Ruoqiang (Charkhlik), through the desert to the southern slopes of the Kum Tagh sand dunes (Figure 1). The desert between the mountains and the dunes is supplied with water from the mountains in summer and autumn. The Annanba Nature Reserve, which was established by Gansu Province in 1982, covers $3900 \mathrm{sq} \mathrm{km}$ and offers limited protection for the wild camels in this area. It is contiguous with the $15,125 \mathrm{sq} \mathrm{km}$ Arjin Shan Reserve to the west, which was established in 1986.

Survey area $\mathrm{D}$ was in the Tarim River basin in the Taklamakan Desert, and extended east and west of the new north-south highway to the oil camp terminal $800 \mathrm{~km}$ south of Luntai. There is much heavy vehicle activity on this road, which bisects camel habitat in the southern reaches of the Tarim basin.

\section{Results}

No camels were seen in survey area A in 1995. The survey covered $1400 \mathrm{~km}$, from Tikar to Yunmenquan, and took 12 days. Three valleys in the Kuruk Tagh mountains were traversed on foot and, in each, recent evidence (droppings and footprints) of both young and adult camels was found. The team visited seven of the area's saline springs and found hunter's hides near four of them. Three water sources near the northern end of Lop Nur, which were 
known to be water points for camels in the early 1980s, were dry. Between the Kuruk Tagh mountains and Lop Nur there were several camel migratory routes and we found signs in three separate areas indicating that groups of up to seven camels had rested. Traditionally, the Uygur people of Tikar hunt camels and, although this is illegal, this practice continues. We found evidence of hunting of camels (three adult skeletons and one young) and of goitred gazelle Gazella subgutturosa (remains of six adults). North of the Aqike Valley, we visited two legal and two illegal gold mines and found the remains of a dead camel near one. It was reported that in 1994 a wild camel had drowned in a pit that had been dug for processing gold. When we returned to the area in 1996, gold mining activity had doubled.

In 1996 we saw eight camels in area A: two lone bulls north of Lop Nur; and two bulls, three females and a yearling in the Aqike Valley. Camel tracks were seen in the dried up bed of Lop Nur. It was reported that some camels winter in the Aqike Valley and cross the dunes to shelter in the valleys of the Aljin Shan mountains in the hot summer months. We only managed to enter the Aqike Valley at the seventh attempt because of the difficult terrain.

In area $B$ we covered more than $700 \mathrm{~km}$ by foot and jeep. We made two surveys on foot to the area overlooking the Dacoatan spring, but were prevented by military personnel from approaching the spring itself, which extends for $100 \mathrm{~km}$ along the border buffer zone. Mongolian herdsmen confirmed that the zone is used by wild camels migrating across the border from Mongolia and reported that they had seen 50 camels there on 19 April 1994. In February 1995 three bull camels in rut came to an encampment $70 \mathrm{~km}$ from the border to try to mate with domestic camels. It was also reported that in 1994 herdsmen in the Kushui area of the Dacoatan spring had seen, on two separate occasions, three Gobi bears Ursus arctos pruinosus, whose world-wide population is not thought to exceed 35. Miners from Xinjiang and Gansu had been fighting over gold-mining rights in the area and a battle with shot-guns had taken place $90 \mathrm{~km}$ south of the Dacoatan spring 2 days before our arrival. We saw a sign $80 \mathrm{~km}$ south of the spring warning herdsmen not to graze livestock because of potassium cyanide contamination.

In area $C$ we covered $800 \mathrm{~km}$ and drove along the abandoned, dilapidated road from Dun Huang to Ruoqiang. We visited Annanba and camped for 5 days in the foothills of the Arjin Shan mountains near the Lapeiquan spring and for 2 days at the head of the valley at Hongliugou. During our stay near Lapeiquan, we carried out five separate surveys on foot and by jeep in the direction of the Kum Tagh sand dunes and observed 49 wild camels, 19 of which were positively identified as females and 12 as young. In addition we saw one female at close quarters in the Kum Tagh with a 7-hour-old calf and two solitary bulls in valleys near Lapeiquan and Hongliugou. We saw hybrid animals in five separate groups of domestic camels. A Kazak herdsman told us that he believed that there were up to 500 wild camels in the Arjin 'Shan mountain area and said that in 1980 a geological survey team had shot 40 wild camels for food.

In area $\mathrm{D}$ we found two old skeletons of wild camels of indeterminate age and sex in the lower reaches of the Tarim River. We made three surveys totalling $30 \mathrm{~km}$ on foot into the Taklamakan Desert to the east and west of the new road leading the the oil camp. In addition we made a $1600-\mathrm{km}$ return trip by road between Luntai and the oil camp. Yuan Guoying reported that he had seen a camel from the new highway in March 1995. We saw evidence of the new highway cutting through the migratory routes of camels.

Our estimates of wild camel numbers in the four survey areas are based on the personal knowledge of Zhao Zijun, discussions with herdsmen, our own observations and published papers. We conclude that $80-100$ remain in survey area $A, 350-400$ in the Trans-Altai Gobi in Mongolia, contiguous to the south with survey area B in China - see Zhriinov and Ilyinsky (1986) and Tulgat and Schaller (1992); 250-300 in survey area C; and $50-80$ in area $D$, giving a total of $730-880$. 


\section{Proposed conservation action}

In area $\mathrm{A}$ we estimate that the camel population has declined by almost 75 per cent since the surveys carried out in 1980 and 1981 (Gu and Gao, 1995). We propose that the Xinjiang Lop Nur Nature Sanctuary, contiguous to the south with the Annanba Nature Reserve and the Arjin Shan Reserve, is established without delay. We propose that the sanctuary should cover $107,768 \mathrm{sq} \mathrm{km}$ between $89^{\circ} 00^{\prime}-93^{\circ} 00^{\prime} \mathrm{E}$ and $39^{\circ} 30^{\prime}-42^{\circ} 30^{\prime} \mathrm{N}$. Except for four gold mines (two of which are illegal), two salt mines and one lead-zinc mine, there are no other mining activities in the area. The sanctuary would be situated in the southern parts of Shanshan County and Hami County, the northern part of Ruoqiang County and the eastern part of Yuli County. The four county authorities have approved the proposal, as has the Xinjiang provincial authority. Once established in law, there would be five check points at Tuokexun, Tikar, Nanhu, Yamansu and Houkeng, with an administrative headquarters in Urumqi. The administration would set up check points, patrol the area, undertake public-awareness programmes, carry out scientific research, provide additional water points for the camels and erect boundary signs. The proposed sanctuary has already received support from the National Environment Protection Agency of China, which has indicated that it will pay the recurrent costs for 10 years if the necessary capital funding can be found. We feel that unless immediate action is taken, this last genetically pure strain of wild camel in the Lop Nur area could be extinct within 5 years.

Strict controls are needed near the Dacoatan spring in area $\mathrm{B}$. We are endeavouring to arrange contact with the appropriate authorities in China and Mongolia so that full protection can be given to camels in the border buffer zone. We are also recommending a ban on the use of potassium cyanide in the goldmining process.

In area $\mathrm{C}$ we recommend a strengthening, through the provision of adequate finance, of the Annanba and Arjin protected areas, and that the potential threat of mining in the Arjin Shan mountains be closely monitored.

In area $\mathrm{D}$ we feel that little can be done for the wild camel because of the intensive oil exploitation and the development of the new highway.

\section{Acknowledgements}

The surveys were conducted at the invitation of the Xinjiang Environmental Protection Bureau with sponsorship from the United Nations Environment Programme. Fauna \& Flora International provided administrative assistance. I would like to thank: Yuan Guoying, Li Hongxh, Yuan Lei and Zhao Zhigang of the Xinjiang Environmental Protection Bureau and, in particular, Zhao Ziyun for his guidance and detailed knowledge of the Lop Nur region.

\section{References}

Bannikov, A. 1976. Wild camels of the Gobi. Wildlife, 18, 398-403.

$\mathrm{Gu}$, Jinghe and Gao, Xingyi. 1985. The wild twohumped camel in the Lop-Nor Region. In Contemporary Mammalogy in China and Japan (ed. T. Kawamichi), pp. 117-120. Mammal Society of Japan, Osaka.

Hedin, S. 1898. Through Asia. Vol. 1. Methuen, London.

Hedin, S. 1903. Central Asia and Tibet. Vol. 2. Hurst and Blackett, London.

Hedin, S. 1940. The Wandering Lake. George Routledge and Sons, London.

Kozlov, P.K. 1899. Proceedings of the Expedition of the Imperial Russian Geographic Society to Central Asia in 1893-1896 under the Leadership of Roborousky. Vol. 2.

Littledale, S. 1894. Field-notes on the wild camel of Lob-Nur. Proc. Zool. Soc. London, 446-448.

Prejavalsky (Przewalski), N. 1879. From Kulja across the Tian Shan to Lob Nur. Sampson. Low, Marston, Searle and Rivington, London.

Tulgat, R. and Schaller, G.B. 1992. Status and distribution of wild Bactrian camels Camelus bactrianus ferus. Biological Conservation, 62, 11-19.

Zhirinov, L. and Ilyinsky, V. 1986. The Great Gobi National Park - A Refuge for Rare Animals of the Central Asian Deserts. Centre for International Projects, Moscow.

J. N. Hare, Wild Camel Protection Foundation, PO Box 856, St Helier, Jersey JE4 OYW, Channel Islands, UK. 